\title{
一般口演 6
}

\section{姿勢記録装置の試作}

\section{A posture recording system for the head and body}

\author{
山田好秋，川原祐三，斎藤米蔵，平野秀利 \\ Yoshiaki YAMADA, Yuzo KAWAHARA, Yonezo SAITO, Hidetoshi HIRANO \\ 新潟大学大学院医歯学総合研究科顎顔面機能学分野 \\ Niigata University Guraduate School of Medical and Dental Sciences, Division of Oral Physiology
}

\section{I. 目的}

近年下顎の機能運動時に頭部も協調して運動するこ とが明らかとなり，その機能的意義が注目を集めてい る.一方，これまでにも姿勢と咬合との関連が示唆され ながらも臨床的な証拠は示されていないだけでなく，基 礎的な研究も限られている。これは頭部の姿勢を長時間 正確に記録する装置が開発されていなかったためと考え られる，姿勢を記録する装置として，歯科の分野では下 顎運動記録に伴う頭位の補正信号を利用する方法 ${ }^{1 ｝{ }^{3)} \text {, }$ および加速度センサにて慣性加速度を記録する方法 ${ }^{4)}$ がとられてきた。一方，医科の分野では主に関節の可動 域を検査することに主眼がおかれ，その中にあって頸部 と体幹の関節可動域が研究の対象となっている ${ }^{2)}$. した がって，いずれの手法も自由行動下に頭位姿勢を記録す ることはできない，今回，加速度センサを使用し頭部 · 体幹の姿勢を矢状面・水平面内で 2 次元的に長時間記録 するシステムを開発したので，その応用例を含め紹介す る.

\section{II. システムの概要}

システムは姿勢の変化を検出する加速度センサ，セ ンサ出力を記録する小型デー夕収録器, モニタならび にデータ解析用パソコンで構成される．加速度センサ は IC 化され $7 \times 10 \times 5 \mathrm{~mm}$ (5-gr) のモジュールに内蔵 されている. しかも, 内部には 2 つの加速度センサが直 交して配列されているため，一つのモジュールで 2 方向 （すなわち一平面）の運動が検出できる。このセンサは
慣性加速度だけでなく重力加速度も検出できるため, 鉛 直軸に対する傾きを精度良く記録できる，本システムで は慣性加速度成分をアナログフィルタにて除去し, 重力 加速度成分の分離を試みた。また，センサは鉛直軸に対 する傾きが検出される機構であるため, 頭部センサと体 幹センサとの差をアナログ回路で求め, 体幹と頭部の関 節角度と体幹の鉛直軸に対する角度を求め記録した.

データ収録器は RS-232C でパソコンと接続し, セン サの出力をモニターすると同時に, 記録時のサンプリン グ速度，記録時間を設定できる，センサモジュールは 2 つ使用し，一方を眼鏡中央に固定し頭部記録用とし，他 方を頸部背側に設置し，体幹記録用とした．記録に先立 ち被験者をまっすぐな姿勢で背もたれのない椅子に座ら せ，フランクフルト平面が水平となる位置でセンサ出力 を原点に設定した。その後, デー夕収録器はモニター用 のパソコンから切り離され, 被験者は装置を伴って自由 に行動できる．記録された時系列デー夕は設定したサン プリング速度で $\mathrm{A} / \mathrm{D}$ 変換され，データ収集装置に用意 された PCメモリカードに保存される。データはテキス 卜形式で格納されるため, 記録終了後はメモリカード をパソコンに装着することで, Excel などのアプリケー ションソフトで目的にあった解析が可能である（図 1 ).

\section{III. システム評価}

図 2 に安静座位で決めた原点から，読書（縦書き書・ 横書き書)，座位（椅子に背筋を伸ばして座る・自由に 座る), 自由歩行 (背筋を伸ばして歩行・自由に歩行), 頭部の屈曲（前後・左右）ならびに頭部回転（右回転・ 
左回転）時の頭位・体位変化を経時的に記録した例を示 す. 全般的には頭部運動と体幹の姿勢変動には関連があ り, 前後的には同位相, 左右的には逆位相で運動するこ とが観察された。

図 3 に読書および頭部回転時の運動軌跡を水平面に投 影して示す.

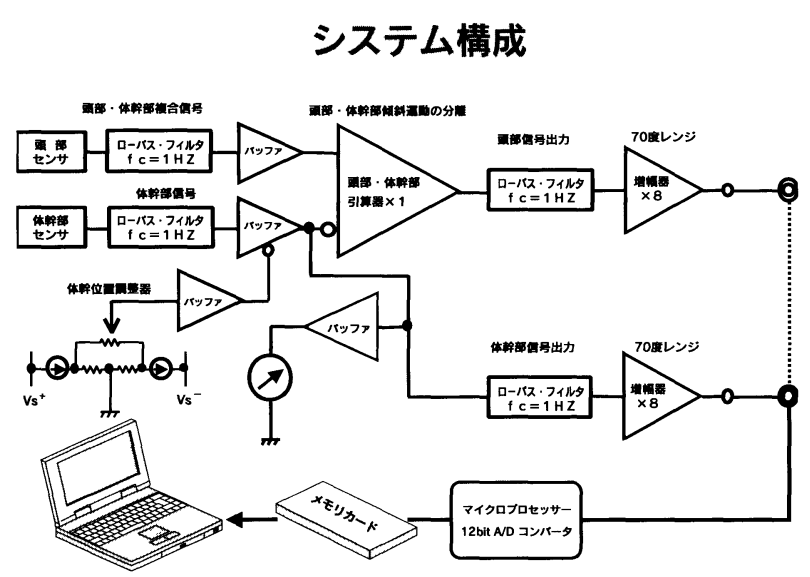

図 1 姿勢測定システム

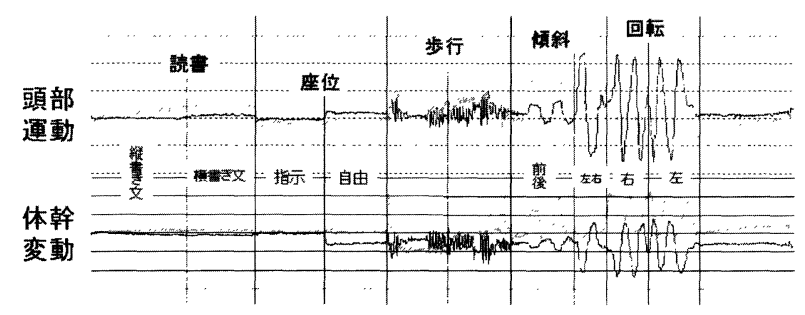

図 2 時系列表示

\section{A Text reading task}

B Head turning task

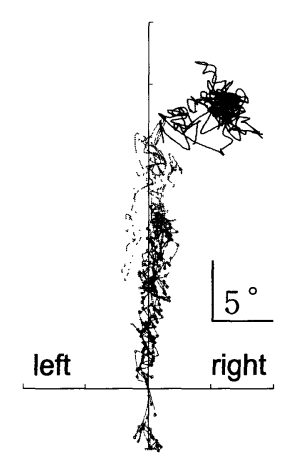

N. 考 察

本研究の目的は頭部・体幹の姿勢を自由運動下に長時 間記録するシステムの開発と, その応用例を示すことに あった，開発した装置はバッテリーの持続時間以外，操 作上に問題点はなく, 特に電子機器に精通するオペレー 夕がいなくとも外来で記録できることが示された。下顎 運動を同時記録することはできないが, 日常生活の中で フランクフルト平面がどのように維持されているか，い わゆる姿勢の悪いと予想される患者がどのような時点で どのような姿勢をとっているのかが, 定量的に検査でき ると結論できる.

頭部の回転運動は頸部に異常を訴える患者では健常者 と異なった運動軌跡が記録されており, 今後頸部の運動 異常を検查することに応用可能であると考えられる.

\section{V. 文献}

1) Eriksson, P. O., Haggman-Henrikson, B., Nordh, E., Zafar, H.: Coordinated mandibular and head-neck movements during rhythmic jaw activities in man. J Dent Res, 79, 1378-1384, 2000.

2 ) Jordan, K.: Assessment of published reliability studies for cervical spine range-of-motion measurement tools. Journal of Manipulative and Physiological Therapeutics 23: 180-195, 2000.

3 ) Kohno, S., Kohno, T., Medina, R. U.: Rotational head motion concurrent to rhythmical mandibular opening movements. J Oral Rehabil, 28, 740-7, 2001a.

4 ) Toris, T., Suenaga, H., Yoshimatsu, T., Kanaoka, R., Yamabe, Y., Fujii, H.: Anticipatory and reflexive neck muscle activities during voluntary rapid jaw opening and passive jaw depression in humans. J Oral Rehab 29: 961-968, 2002.

図 3 水平面投影図 